\title{
Comparative Issues on American and Brazilian Electoral Politics: an Interview with Dr. Royce Carroll
}

\author{
Alessandro Faraje Figueiredo ${ }^{1}$
}

\begin{abstract}
:
In this interview, Royce Carroll discusses many differences and similarities concerning American and Brazilian politics. The issues include electoral system differences, political party discipline, religious vote, media and the like.
\end{abstract}

Royce Carroll is Reader in Comparative Politics at the University of Essex and he was an Associate Professor of Political Science at Rice University. His research focuses on democratic institutions and the role of representation in the policy-making process, particularly legislative politics and the politics of coalitions within and between political parties. His recent research focuses on political parties, the distribution of legislative power and on the spatial analysis of political choices in the measurement of preferences and ideology. This interview happened in 2012 during my Split-site PhD term at USA, between many lessons and meetings where Dr. Carroll was always open to discuss many Political Science topics and review students' papers.

\footnotetext{
1 Dr. Alessandro Farage Figueiredo é Cientista Político, Jurista, Sociólogo e Demógrafo. Pós-Doutorado em Desenvolvimento Internacional pela University of Denver. Pós-Doutorando em Ciência, Tecnologia e Educação pelo CEFET/RJ. Tem o website https://plus.google.com/+AlessandroFarageFigueiredo e seu e-mail é alefarage@gmail.com CV completo: http://lattes.cnpq.br/2773646156482036
} 
Leviathan: First of all, I would like to talk about the electoral system differences between Brazil and United States. For many Brazilian scholars, the Brazilian electoral system is considered more effective due to having a more representative number of parties. They are critics of the American electoral system, where just two political parties are significant. How do you consider such observations and differences?

Carroll: Critiques of the two party system are common within the US as well. In general discourse most of these lean toward preferring more non-partisans (that is, "independents"), but there are certainly many activists and academics who would favor a system of party list proportional representation more like Brazil's. The potential benefits of the current electoral system should first be noted. When the US electoral system was designed, political parties as we know did not yet exist. Legislative elections were designed to maintain a connection between individual members of Congress and local interests. The threat of majoritarian political centralization was a salient issue at the time of constitutional ratification, and the framers of the US Constitution believed that legislators would compete with one another in the formulation of policy because they represented a disparate set of local, state and regional interests. Only as parties later emerged to structure competition for the presidency and coordinate political activity within Congress did the party system effects of the electoral system became apparent. As voters came to develop loyalties to parties -- and especially as federal elections became more important -- there was eventually a great advantage for serious candidates on joining one of the two parties and a tendency for voters to perceive other candidates as non-viable. Today, third parties are largely irrelevant. However, for much of the time since the two party system was fully institutionalized these two parties have still existed alongside a relatively individualized accountability structure for members of Congress. In this sense, a great deal of regional and ideological diversity was still present within the two parties, while the overall bipolar structure has provided some benefits such as simplifying the basic direction of policy alternatives for the electorate. Of course, the 
modern Brazilian political system shows how a generally bipolar relationship among the major parties can exist in conjunction with a more complex party system in the legislature.

There are several arguments sometimes made about potential downsides of adopting a PR system in the US. One is the loss of the relationship between a district and a single member of Congress. This is partly mitigated by Brazil's "open list" system of PR and by other variants such as New Zealand's mixed PR system (which retains individual member districts). A related point is that party list systems can give party leaders more control over individual members, and parties are historically unpopular in the US relative to individual members of Congress. Another concern sometimes raised is the potential ease with which extremist movements might obtain political influence if new small parties could easily form and win elections. Finally, some political scientists have criticized party systems like that of Brazil for being difficult to govern due to the proliferation of parties.

But there are serious concerns about the functioning of the US two party system. In recent years, the pattern of flexible bipolarity in the US has given way toward a much more rigid two-party system. In the context of the separation of powers, this has led to an unprecedented degree of gridlock in recent years. The parties are not flexible enough to enable bargaining over policy, even on major and urgent issues. Moreover, party elites seem to have become more ideologically homogeneous. This has led to many groups in society feeling unrepresented by the two parties, while alternative parties remain nonviable. Such voters may be more satisfied with democracy if more viable parties were able to compete for their votes. Electoral reforms are not on the agenda in the US, however, and frustrations with the party system have led more to a populist anti-party sentiment, both ideological and pragmatic. An electoral system more like Brazil's, which allows the party system to change fairly easily as society changes, could provide some advantages over the current US system. It should be noted, however, that when comparing electoral systems between nations one cannot separate the functioning of the legislatures and its election rules from the rest of the political environment. Brazil differs in several other important respects that must be taken into account, notably the 
considerable legislative powers of the presidency.

Leviathan: Nowadays the Brazilian political science is giving a lot of attention to the topic of political party discipline as it is important for executive coalition. How does this situation looks like in the USA, considering that legislators are very connected to their districts and there are only two political parties in power? How do American legislators decide when voters at their districts have a different opinion from their political parties?

Carroll: Party discipline is weaker in the US compared to many countries in the world. Because parties have weak control over party nominations in the US, they are not in a strong position to impose discipline. Still, party leaders can influence many internal paths to advancement and members face incentives to vote with the party, at least when it does not create a major cost for their reputation in their district. Generally, members facing districts where the opposite party is strong will face pressure to vote against their party (at least on salient issues) and they often do so. In recent times, voting with the opposite party is less common but there is no doubt that the reputation developed in the district through the voting record remains very important. Voting behavior on major issues is routinely used in campaigns when opponents perceive those votes as unpopular in the district. It is important to note, however, that increasingly the most important part of the district constituency in the US is the primary electorate within their party. Catering to that audience may have the effect of reinforcing party unity, especially in districts where the general election is not competitive.

The relationship between executive power and party unity depends on whether the president's party controls the legislature. Recently, a high degree of party unity has meant the president lacks a consistent legislative support without controlling both houses of Congress, which currently requires a supermajority in the Senate due to the persistent use of the 'filibuster' to prevent votes on legislation (this rule effectively requires a majority of 60 Senators to allow a vote). With only two parties, each relatively disciplined, ad hoc 
coalitions for legislation including members of both majority and minority parties are no longer common.

Leviathan: The issue of district vote in the U.S. has raised a lot of controversy with respect to redistricting and the way it is used by politicians to search for better results. Could you explain this situation about redistricting and talk a bit about how this is linked with the dominance of only two parties in the American political scene?

Carroll: As I mentioned before, single member districts usually create incentives to reduce the number of major candidates to two in each district. This has translated into two parties nationally for a variety of reasons, including the process of competing for the presidency. At this point, the two parties also have a great deal of integration with the legal rules surrounding the election process, such that it would be extremely difficult for another party to compete, even if it could convince voters to vote for its candidates. The existence of primary elections also reduces the prospect of third party candidates, since various interest groups can directly influence the nominee of either party. This is often a viable path for new political forces to gain influence.

The process of redistricting is one of the most questionable byproducts of having many geographically compact districts. Although redistricting prevents malapportionment -something that in Brazil results in significant distortions of influence even in the lower house -- it also creates an opportunity to make districts match parties' optimal goals for maintaining power. Although some redistricting processes are non-partisan, historically it has been a means by which a party that controls the state government can make it somewhat more difficult for their opponents to win seats. It has had the effect of insulating members from vote swings and slowing the process of political change in states.

Leviathan: There is a perception that there is a regionalization of votes in Brazil, with the PSDB getting his best electoral results for president in the south and southeast regions while PT gets superior results in the northeast. Similarly, it is observed in the U.S. that 
some states support the Republican Party in various elections and others typically support the Democratic Party. Could you explain the relationship between votes and certain regions?

Carroll: Like Brazil, demographic factors related to presidential voting often correlate with geographic regions. Since the late 1990s, the South and non-coastal West tends to vote Republican, while the Northeast, West Coast and the Great Lakes areas tend to vote Democratic. The differences within regions are also important, though the consistency of local partisan majorities gives the impression that states favor certain parties as a whole. White voters in the South consistently vote Republican (after having previously voted for the Democratic Party before the 1960s). Black voters have become consistently Democratic since the 1960s Civil Rights Era and also make up a substantial portion of the Southern population. Overall, the region consistently favors Republicans, but the voting is actually polarized by race. In the Northeast, the current tendency toward the democrats is fairly pervasive, but in other regions the Republicans tend to dominate in rural areas while Democrats dominate urban areas. States that, as a whole, appear consistently Democratic tend to have large or dense cities with less rural population. In the Northeast, which is socially liberal, the Democratic voting tendency is strong even in some rural areas. Also, areas with large Latino populations, especially in the Southwest, tend to vote Democratic.

Leviathan: Another issue very criticized in Brazil is the fact that religious question seem to be very prominent in American presidential elections. Although in Brazil there are also those who aim at the religious voters, a candidate's religious views are not the most prominent theme in Brazilian presidential campaigns. Why is there this difference? Why is religion so important in the U.S. presidential election? How do you explain the situation of the "Bible belt" in American elections?

Carroll: The US is known to be more religious compared to most other advanced democracies, such as those in Europe, though this would not be the main reason for 
differences from Brazil in the political use of religion. I should note that I am not an expert on religion in politics, but I would contend that the prominence of religion in current US politics derives from its relationship to other issues. That is, religious language can be a useful signal of substantive policy positions as well as more vague identity politics. Religion therefore correlates heavily with other political trends and is largely aligned with the overall ideological and partisan divide. The "Bible Belt" refers to the concentration of Evangelical Christians in the South who are now fairly reliable Republican voters, with the Republicans often appealing to both specific social issues (especially abortion and gay rights in recent years) and a more general sense of cultural nationalism.

Leviathan: With the election of Barack Obama in 2008, numerous political analysts discussed the significance of race in the election of a black man for president of the United States. Similarly, there was more substantial participation of women in the presidential race with the presence of Hilary Clinton and Sarah Palin. In the 2012 election, we had Mitt Romney who is a Mormon. How is the presence of these political actors perceived in the U.S.? How American political scientists are interpreting these changes?

Carroll: My impression -- although this is not my field of expertise -- is that it is a lagging indicator of a generational shift happening in many aspects of American society. Many Americans have been comfortable with women and minority candidates for some time and we've recently passed the point at which such candidacies are clearly viable. This doesn't yet apply to all backgrounds, but each case you mention reflects significant progress toward equal opportunity in political representation.

Leviathan: While the U.S. political scene is dominated by two major parties (Republican and Democrat), there are other smaller political parties. Do these small political parties have some local or regional importance? Can they elect mayors, city councilman and congressmen? What is their current role?

Carroll: For the most part, politicians are inclined to affiliate with one of the major parties 
because they are otherwise perceived as non-viable. At the municipal level, the main exception to national party affiliation is, of course, non-partisanship. Many local elected officials have no formal affiliation. However a number of local officials do affiliate with small parties, such as the Green Party. At the state level, representation for third parties is also exceptional, but nevertheless exists. One fairly successful party of this sort is the Progressive Party in Vermont which currently has five seats in their state legislature. Vermont also elected one of the independents in the US Senate - a politician who would be likely to be a part of a viable left-wing party if one existed. Despite these successes, the main impact of these parties in the general election -- except in cases where one major party is not competing -- is to split the vote and help elect the major party that would probably be least preferred candidate for those voters. The Green Party in the presidential race in 2000 was a famous example of this (where Florida went to George W Bush), but third parties often change the outcome of other races. For example, several House and Senate races in 2012 were won by Democrats with margins smaller than the share of the vote received by the Libertarian Party candidate (an economically right-wing minor party). The Democrats did not oppose the aforementioned Vermont Senator in the election for this reason -- treating him as a de facto Democrat. One reason why third party demand remains so small is that, in addition to the strategic incentives not to vote for them, the party primaries allow a wide range of ideologies to compete for the nomination and provide a more attractive means for activists to have their voices heard.

Leviathan: In Latin America, the media involvement with politics is viewed with distrust by many scholars, with varied criticisms and accusations from media companies siding with the ruling party to newspapers in favor of a certain party or candidate. In the U.S. these criticisms are sometimes observed in relation to FOX News and MSNBC. What is the status of these two stations in the U.S. politics? How is the general relationship between media and politics in USA?

Carroll: Generally, the tendency among the public has been toward less trust of the media 
and no single source of news is universally trusted. Both Fox News and MSNBC do now provide commentary on current events from a political perspective, with the former being especially influential in the politics of the Republican Party. There has been a tendency for media fragmentation to isolate the information sources of voters more generally, magnified by the internet. The result is a reduced tendency for voters to access information that would provide a perspective contrary to their own political views. As traditional media organizations decline, TV networks are trying to find a market in an audience interested in this sort of content.

Leviathan: The U.S. presidential campaigns appear to be the most sophisticated in terms of political tools and marketing, such as polls, advertising, caucuses, and other activities. The early caucuses are a huge event and the party primaries have a dynamic that is similar to the valid electoral race. Is this long and complex electoral calendar, a feature only of the U.S.? Or is it a trend to be observed by other democracies? What is the role and importance of marketers, advertising, and polls in the US electoral race?

Carroll: Certainly, polling and advertising are a huge part of US presidential politics and are part of the reason the campaigns require extensive fundraising. US primaries are indeed very formalized and institutionalized and nearly function as an official "first round" in the electoral system. They allow the parties to integrate potentially competing movements into their coalitions and they provide a testing ground for campaign ability. Although some countries use party primaries for presidential elections, I don't expect other countries to adopt primaries as institutionalized as the American ones. There is some possibility that the presidential primary system could be reformed if parties decide that it is no longer suiting their purposes. Such reforms have occurred in the past. Some Republicans voiced concern about whether the 2012 primary process was harmful due to the prominent voice it gave to some controversial stances. 